\title{
Y chromosome microdeletions screening in Tunisian infertile men
}

\author{
Recherche des microdélétions du chromosome Y \\ chez des patients tunisiens infertiles
}

\author{
Ines Chabchoub ${ }^{1,2}$ \\ Moez Kdous ${ }^{3}$ \\ Fethi Zhioua ${ }^{3}$ \\ Amel Gaied ${ }^{2}$ \\ Ghaya Merdassi ${ }^{1,3}$ \\ ${ }^{1}$ Département des sciences \\ pharmaceutiques $\mathrm{A}$, \\ Faculté de pharmacie de Monastir, \\ Tunisie \\ ${ }^{2}$ Laboratoire de génétique, \\ immunologie et pathologie humaine, \\ Faculté des sciences de Tunis, Tunisie \\ ${ }^{3}$ Unité de procréation médicalement \\ assistée, Département de gynécologie \\ et obstétrique, Hôpital Aziza Othmana, \\ Tunis, Tunisie
}

\begin{abstract}
The aim of this study was to establish the prevalence of chromosomal abnormalities and microdeletions on the $\mathrm{Y}$ chromosome in Tunisian infertile men with severe oligozoospermia or non-obstructive azoospermia. In cases of azoospermia, we aimed also to correlate histological results after negative testicular sperm extraction with the type of Y chromosome microdeletion. 84 infertile patients and 52 controls were screened for karyotypic abnormalities using Gbanding and Yq chromosome microdeletions using multiplex PCR. 7 infertile males $(8.3 \%)$ carried chromosomal abnormalities and $8(9.5 \%)$ presented Y chromosome microdeletions. The frequency of chromosome abnormalities in azoospermic patients was $11.1 \%$ vs $3.3 \%$ in the severe oligozoospermic group. Klinefelter syndrome was the most frequent chromosomal abnormalities in $85.7 \%$ of cases. Only one patient had a 46,X,del Y/45,X karyotype. The frequency of microdeletions was $11.1 \%$ in the azoospermic group and $6.7 \%$ in the severe oligozoospermic group. Six out of 84 (7.14\%) of the infertile patients had microdeletions in the AZFc region, one azoospermic male had microdeletion in the AZFbc regions and one in the AZFb region, no deletions in the AZFa region. Among the 6 azoospermic patients with microdeletions: 4 had Sertoly cell only syndrome (SCOS) and 2 had maturation arrest (MA). Genetic abnormalities in infertile Tunisian patients are similar to those reported in other countries. The knowledge of the existence of genetic abnormalities and microdeletions is useful to provide a correct diagnosis and it allows the clinician to refer the patient to adequate assisted reproduction technique and examine the value of testicular biopsy pertinence.
\end{abstract}

Key words: infertility, $Y$ chromosome microdeletions, AZF, azoospermia, oligozoospermia

Résumé. L'objectif de cette étude était d'établir la prévalence des anomalies chromosomiques et des microdélétions du chromosome Y chez des patients tunisiens infertiles ayant une oligozoospermie sévère ou une azoospermie non obstructive. Dans les cas d'azoospermie, nous avons cherché aussi à corréler les résultats histologiques après biopsie testiculaire négative avec le type de microdélétions du chromosome $\mathrm{Y}$ trouvé. 84 patients infertiles et 52 contrôles ont été criblés pour la recherche des anomalies de caryotype par la méthode des bandes $\mathrm{G}$ et des microdélétions du chromosome Yq par PCR multiplexe. Sept hommes infertiles $(8,3 \%)$ portaient des anomalies chromosomiques et 8 $(9,5 \%)$ ont présenté des microdélétions du chromosome Y. La fréquence des anomalies chromosomiques chez les patients azoospermiques était de 11,1\% vs 3,3 \% dans le groupe des oligozoospermies sévères. Le syndrome de Klinefelter était parmi les anomalies chromosomiques les plus fréquentes dans $85,7 \%$ des cas. Seulement un patient avait un caryotype 46,X,Ydel/45, X. La fréquence des microdélétions était de 11,1\% dans le groupe des azoospermies 
et $6,7 \%$ dans le groupe des oligozoospermiques sévères. 6 des $84(7,14 \%)$ patients infertiles avaient des microdélétions dans la région $\mathrm{AZFc}$, un patient azoospermique avait une microdélétion dans les régions $\mathrm{AZFbc}$ et un autre dans la région $\mathrm{AZFb}$. Aucune délétion dans la région $\mathrm{AZFa}$ n'a été détectée. Parmi les 6 patients azoospermiques avec microdélétions, les résultats histologiques ont montré que 4 patients avaient le syndrome de cellules de Sertoli seulement (SCOS) et 2 patients présentaient un arrêt de la maturation (MA). Les anomalies chromosomiques et les microdélétions du chromosome Y chez les patients tunisiens infertiles sont fréquents et similaires à ceux rapportés dans d'autres pays. La connaissance de l'existence d'anomalies génétiques et de microdélétions est utile pour établir un diagnostic correct de l'infertilité masculine, il permet au clinicien d'orienter le patient à la technique de procréation médicalement assistée la plus adéquate et d'évaluer la pertinence de la biopsie testiculaire.

Mots clés : infertilité, microdélétions du chromosome Y, AZF, azoospermie, oligozoospermie

Infertility is defined as the inability to conceive after one year of unprotected intercourse [1]. It affects 10 to $15 \%$ of couples attempting pregnancy. Nearly $50 \%$ of these cases are accountable to the male partner [2]. Numerous factors have been identified for male infertility; to start with genetic factors were implicated in $10 \%$ of cases. These genetic disorders affect semen parameters by causing alteration of chromosome materials. Recently, many researchers had reported a close relation between $\mathrm{Y}$ chromosome microdeletions and male infertility [3, 4]. Moreover, great association with birth defects and miscarriage has been reported [5]. The investigation of male infertility should include the identification and the analysis of chromosomal anomalies, the most frequent genetic causes of this condition [6]. The incidence of chromosomal abnormalities is about ten times higher in infertile men than in the general population [7]. Klinefelter syndrome, 47, XXY and its variants are the most common chromosomal aberrations among men, with an estimated frequency of 1:500 among newborns [8].

After the Klinefelter syndrome, Y chromosome microdeletions are the leading genetic causes of male infertility [9]. Different studies have shown that the three microdeletions of the azoospermia factor; AZFa, AZFb and AZFc was seen in $10 \%$ of azoospermic men. These deletions remove many genes likely involved in male germ cell development and maintenance [10]. The genes in the AZF region are considered critical for spermatogenesis, and the frequency of microdeletions in the Yq region has been associated with the severity of the spermatogenic defects [11]. This predisposition for infertility can also include gradual alterations in spermatozoa production such that men with oligozoospermia may later develop azoospermia [12].

Chromosomal abnormalities and Y chromosome microdeletions may be transmitted to future generations by assisted reproduction techniques (ART), clinical diagnosis of the cause of infertility is mandatory. The primary aim of this study was to establish the prevalence of chromosomal abnormalities and microdeletions on the $\mathrm{Y}$ chromosome in Tunisian infertile men with severe oligo-zoospermia or non-obstructive azoospermia. In cases of azoospermia, to correlate the genotype with the observed phenotype.

\section{Materials and methods}

\section{Patients}

In this prospective study, patients were recruited consecutively from our Assisted reproduction center. The population consisted of 84 infertile Tunisian males with non-obstructive azoospermia or severe oligozoospermia according to World Health Organization guidelines 2010 (sperm count $<5 \times 10^{6} / \mathrm{mL}$ ) [13] who was planning to undergo IVF/ICSI due to male factor infertility. Patients with sperm counting higher than 5 million $/ \mathrm{mL}$ or with obstructive azoospermia or monomorphe teratospermia were excluded. The control group consisted of 52 individuals with normal semen analysis who were attending any assisted reproductive technique due to exclusively primary or secondary (same partner) female factor infertility. Semen samples were produced by masturbation and collected in wide mouthed collection vials. Only patients and controls born in Tunisia and with Tunisian parents were included in this study. All participants gave informed consent according to the protocol approved by the ethics review board.

\section{Variables of interest}

We gathered pieces of useful information related to: age; family history of infertility; tobacco use, medical 
history (cryptorchidism, genital trauma, mumps infection, prostatitis, varicocele, or sexually transmitted disease) previous pelvic surgery; bilateral testicular hypotrophy (estimated clinically), plasma hormone levels (FSH, LH, testosterone), cytogenetic analysis with karyotype, Y chromosome microdeletions and histological examination of testicular tissue (only in azoospermic men when testicular biopsy showed no spermatozoa).

\section{Plasma hormone levels}

The plasma concentrations of follicle-stimulating hormone (FSH) and luteinizing hormone ( $\mathrm{LH})$ were measured by immunoassay using an $\mathrm{IM}^{\circledR} \mathrm{X}$ system kit (Abbott Laboratories, Abbott Park, IL, USA), while plasma testosterone levels were determined by radioimmunoassay using a CoatA-Count ${ }^{\circledR}$ Testosterone Total kit (Diagnostic Products Co., Los Angeles, CA, USA) according to manufacturer's instructions. Normal reference ranges for men are FSH 1-12 $\mathrm{mIU} / \mathrm{mL}, \mathrm{LH} 2-12 \mathrm{mIU} / \mathrm{mL}$ and testosterone $262-1,593 \mathrm{ng} / \mathrm{dL}$.

\section{Cytogenetic analysis}

Chromosomal analysis was performed using phytohemagglutinin-stimulated peripheral lymphocyte cultures as standard cytogenetic technique. The number of metaphases analyzed followed the criteria recommended by Hook for detecting $8 \%$ mosaicism in 40 metaphases, with a confidence interval of $95 \%$. A resolution of 550-band stage was considered satisfactory. The routine analysis was based on G- bands by trypsin using Giemsa GTG-banded staining $[14,15]$.

\section{Molecular analysis}

Peripheral blood was collected from each patient using vacutainer EDTA-containing tube (Becton Dickinson, UK Ltd, Plymouth, England). Genomic DNA was extracted from peripheral blood, according to a standard protocol. Yq microdeletions were performed according to the European academy of andrology (EAA) and the European molecular genetics quality network (EMQN) [16]. The multiplex-PCR was used to detect sequence tagged sites (STS) of AZF microdeletions, a set of 6 STS was chosen for molecular screening in two steps. In the first step, the multiplex A containing: SY86 (AZFa), SY127 (AZFb) and SY254 (AZFc) and in the second multiplex B: SY84 (AZFa), SY134 (AZFb) and SY255 (AZFc). Each PCR multiplex was carried out in $25 \mu \mathrm{L}$ reaction volumes containing: 50 ng genomic DNA, $12.5 \mu \mathrm{L}$ of master mix QIAGEN, $2.5 \mu \mathrm{L}$ of multiplex A or B. Multiplex PCR was performed under the same PCR conditions as follows: initial denaturation at $95^{\circ} \mathrm{C}$ for 15 min followed by 35 cycles of denaturation at $94^{\circ} \mathrm{C}$ for $30 \mathrm{~s}$, annealing at $57^{\circ} \mathrm{C}$ for $1 \mathrm{~min} 30 \mathrm{~s}$, extension at $72^{\circ} \mathrm{C}$ for $1 \mathrm{~min}$ and a final extension at $72^{\circ} \mathrm{C}$ for 10 min. PCR products were separated on $2 \%$ agarose gel electrophoresis, stained with ethidium bromide, and visualized using the Gel Doc system. Microdeleted sample was performed at least three times. In each multiplex PCR assay, healthy female and fertile male were used as negative and positive controls.

\section{Testicular sperm extraction (TESE)}

The testicular biopsies (TESE) were performed superficially only in azoospermic patients. The tunica albuginea was incised transversely for about $5 \mathrm{~mm}$ in each testis proximal to the sites of the needle sampling. The testis was then gently squeezed and the protruding tissues were excised. Smears of each testicular biopsy were taken immediately to be used as an additional means of sperm identification and for cytological evaluation if no spermatozoa detected. The biopsy material was inserted into 2 separate tubes containing Spermrinse ${ }^{\mathrm{TM}}$ medium (Vitrolife ${ }^{\circledR}$, Sweden) and transferred to the laboratory for sperm search and isolation. The tunica albuginea was closed using $6 / 0$ nylon monofiber and the layers of scrotum were sutured separately. Procedures were performed in the day-surgery clinic. After recovery from anesthesia, the men were discharged and advised to rest for 2 hours. They all received prophylactic antibiotic treatment and were re-examined 1 week later. In the laboratory, the testicular tissue samples taken from each testis were treated and examined separately. Each sample was minced using 25-gauge sterile needles. The shredded tissue was collected, centrifuged at $300 \times \mathrm{g}$ for $5 \mathrm{~min}-$ utes and, after removing the supernatant, the pellet was suspended in G-IVF medium (Vitrolife ${ }^{\circledR}$, Sweden). The isolated spermatozoa were cryopreserved to perform ICSI later.

\section{Statistical analysis}

Results are reported as \% or mean \pm SD. Statistical differences between 2 means were obtained using the Student's 2-tailed unpaired $t$ test. For multiple comparisons, 1-way analysis of variance was used. Data were considered statistically significant when $p<0.05$. All analyses were performed using the SPSS software for Windows (SPSS, version 20, SPSS Inc., Chicago, IL, USA).

\section{Results}

One hundred thirty six males were analyzed, 52 fertile males with normal semen parameters (mean age, 38.2 \pm 5.2 ) and 84 infertile (54 azoospermic and 30 severe 
Table 1. Demographic characteristics of patients and controls.

\begin{tabular}{|llll|}
\hline \multirow{2}{*}{ Variables } & Controls & Infertile patients & $\mathbf{n}=\mathbf{8 4}$ \\
\cline { 2 - 3 } & $\mathbf{n}=\mathbf{5 2}$ & $39.3 \pm 5.6$ & 0.22 \\
\hline Mean age; year $\pm \mathrm{SD}$ & $38.2 \pm 5.2$ & $9.2 \pm 4.1$ & 0.03 \\
\hline Duration of infertility; year $\pm \mathrm{SD}$ & $3.5 \pm 1.4$ & $30(35.7)$ & 0.28 \\
\hline Tobacco, $\mathrm{n}(\%)$ & $18(34.6)$ & $15(17.8)$ & 0.023 \\
\hline Family infertility history, $\mathrm{n}(\%)$ & $2(3.8)$ & 1 & 0.8 \\
\hline Criptorchidism, $\mathrm{n}(\%)$ & 0 & 2 & 0.88 \\
\hline Prostatitis, $\mathrm{n}(\%)$ & 0 & 0 & - \\
\hline Mumps infection, $\mathrm{n}(\%)$ & 0 & $4(4.7)$ & 0.9 \\
\hline Sexual transmitted disease & $3(5.7)$ & $10(11.9)$ & 0.031 \\
\hline Varicocele, $\mathrm{n}(\%)$ & $1(1.9)$ & $8(9.5)$ & 0.017 \\
\hline Varicocelectomy, $\mathrm{n}(\%)$ & 0 & 1 & 0.8 \\
\hline Genital trauma, $\mathrm{n}(\%)$ & 0 & $16(19)$ & 0.044 \\
\hline Testicular hypotrophy, $\mathrm{n}(\%)$ & 0 & $14.52 \pm 11.05$ & 0.01 \\
\hline FSH level, $\mathrm{mlU} / \mathrm{mL} \pm \mathrm{SD}$ & $7.22 \pm 3.14$ & $5.06 \pm 2.68$ \\
\hline LH level, $\mathrm{mlU} / \mathrm{mL} \pm \mathrm{SD}$ & $4.82 \pm 1.12$ & $422 \pm 195$ & 0.72 \\
\hline Testosterone level, $\mathrm{ng} / \mathrm{dL} \pm \mathrm{SD}$ & $531.32 \pm 112$ & All Tunisian \\
\hline Ethnicity & All Tunisian & & 0.96 \\
\hline
\end{tabular}

Table 2. Genetic chromosomal abnormalities and Yq microdeletions.

\begin{tabular}{|c|c|c|c|}
\hline & \multirow[t]{2}{*}{$\begin{array}{l}\text { Controls } \\
n=52\end{array}$} & \multicolumn{2}{|c|}{$\begin{array}{l}\text { Infertile patients } \\
n=84\end{array}$} \\
\hline & & $\begin{array}{l}A Z \\
(n=54)\end{array}$ & $\begin{array}{l}\text { So } \\
(n=30)\end{array}$ \\
\hline Klinefelter syndrome homogenous $(47, \mathrm{XXY})$ & 0 & $5(9.2 \%)$ & 0 \\
\hline Klinefelter syndrome mosaic $(47, \mathrm{XXY} / 46, \mathrm{XY})$ & 0 & 0 & $1(3.3 \%)$ \\
\hline $46, \mathrm{X}$ del $\mathrm{Y} / 45, \mathrm{X}$ & 0 & $1(1.8 \%)$ & 0 \\
\hline AZFa & 0 & 0 & 0 \\
\hline $\mathrm{AZFb}$ & 0 & $1(1.8 \%)$ & 0 \\
\hline AZFc & 0 & $4(7.4 \%)$ & $2(6.7 \%)$ \\
\hline AZFbc & 0 & $1(1.8 \%)$ & 0 \\
\hline
\end{tabular}

AZF: azoospermia factor, AZ: azoospermia, SO: severe oligozoospermia.

oligozoospermic) males (mean age, $39.3 \pm 5.6$ ). Table 1 describes their demographic characteristics.

\section{Cytogenetic evaluation}

Chromosome analysis was performed to analyze 40 metaphases for each patient and control. No chromosomal abnormalities were detected in controls and 7 [8.3\%; CI 3.916.4] abnormalities were identified in infertile males. Six out of 7 aberrations were detected among azoospermic men: five presented a Klinefelter syndrome $(47, \mathrm{XXY})$; and one had a 46,X,delY/45,X karyotype. The frequency of chromosome abnormalities in azoospermic patients was $11.1 \%$ (6/54). One severe oligozoospermic man out of 30 (3.3\%) presented an abnormal karyotype with mosaic Klinefelter's syndrome [47,XXY/46,XY] (table 2).

\section{Y chromosome microdeletion screening}

All 136 males were screened for the presence of microdeletions in the $\mathrm{Y}$ chromosome. No microdeletions were identified in any of the control males. Microdeletions were found in 8 of 84 [9.5\%; CI 4.1-17.2] infertile males. The frequency of microdeletions was $11.1 \%(6 / 54)$ in the azoospermic group and 6.7\% (2/30) [CI 1.1-22.3] in the severe oligozoospermic group. Six out of $84(7.14 \%)$ of the infertile patients had microdeletions in the AZFc region (4 azoospermic and 2 severe oligozoospermic males), 1 azoospermic male (1.19\%) in the AZFbc regions and also one in AZFb (1.19\%) (figure 1). No deletions in the AZFa region were detected (figure 2 and table 2).

Testicular sperm extraction (TESE) was performed in 48/54 azoospermic patients ( 6 patients with no Yq microdeletion refused to continue the protocol). Spermatozoa was found 


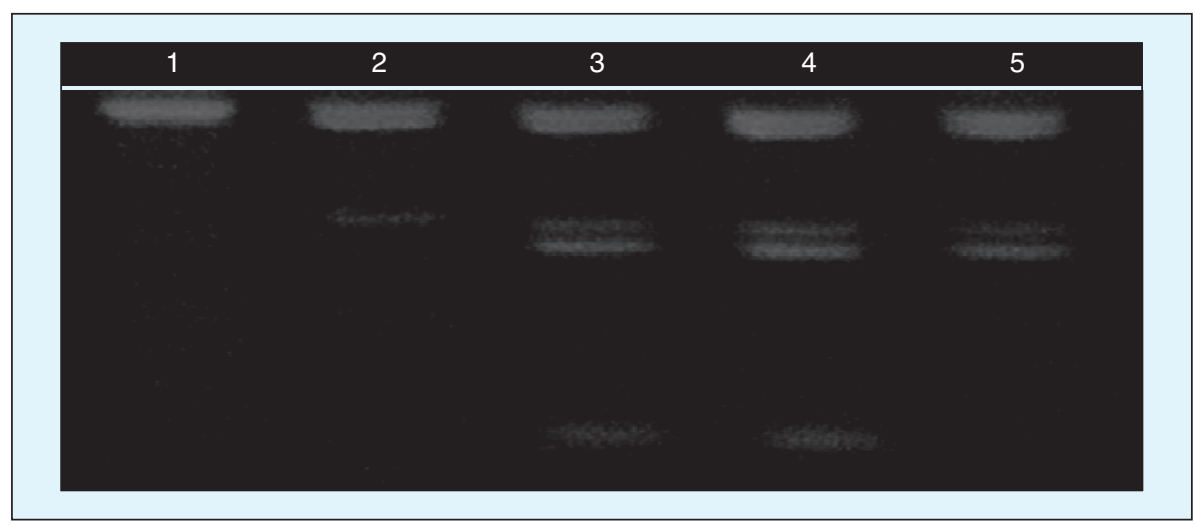

Figure 1. Multiplex B: lane 1 female DNA, lane 2 AZFbc deleted patient, lane 3 and 4 DNA of normal male, lane 5 AZFc deleted patient. Band 1: ZFY (495 pb), band 2: SRY (472 pb) band 3: sY84 (326 pb) AZFa, band 3: sY134 (301 pb) AZFb, band 4: sY255 (123 pb) AZFc.

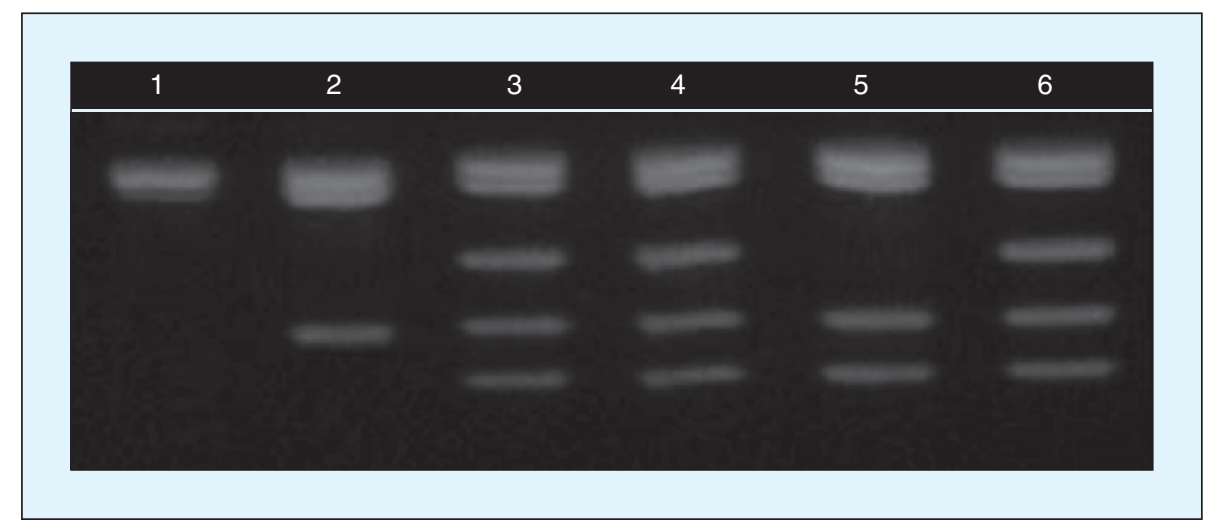

Figure 2. Multiplex A: lane 1 female DNA, lane $2 A Z F b c$ deleted patient, lane 3,4 and 6 DNA of normal male and lane 5 AZFc deleted patient. band 1: ZFY (495 pb), band 2: SRY (472 pb), band 3: sY254 (380 pb) AZFc, band 4: sY86 (318 pb) AZFa, band 5: sY127 (274 pb) AZFb.

Table 3. TESE and cytological findings according to Yq microdeletions in azoospermic patients.

\begin{tabular}{|c|c|c|c|c|c|}
\hline & \multirow[t]{2}{*}{$N=48$} & \multirow{2}{*}{$\begin{array}{l}\text { Microdeletion } \\
(-)\end{array}$} & \multirow{2}{*}{$\begin{array}{l}\text { Microdeletion } \\
(+)\end{array}$} & \multicolumn{2}{|c|}{ Histological examination } \\
\hline & & & & scos & MA \\
\hline TESE $(+)$ & 13 & $13(100 \%)$ & 0 & - & - \\
\hline TESE (-) & 35 & $29(82.8 \%)$ & $6(17.2 \%)$ & $24(68.57 \%)$ & $11(31.42 \%)$ \\
\hline
\end{tabular}

TESE: testicular sperm extraction, SCOS: Sertoly cell only syndrome, MA: maturation arrest.

in only 13 patients who had benefited from sperm cryopreservation (TESE +). For all other patients histological examination of testicular tissue was performed (table 3). Among the 6 azoospermic patients with microdeletions: 4 had Sertoli cell only syndrome (SCOS) and 2 had maturation arrest (MA) (table 3). The correlation between chromosomal abnormalities, cytological finding and $\mathrm{Yq}$ microdeletions is summarized in table 4.

\section{Discussion}

Several factors, including genetic abnormalities, play a crucial role in the diagnosis of male infertility. In our population there was a significant association between infertile men and duration of infertility, family infertility history, varicocele, bilateral testicular hypotrophy and high FSH level. In general, patient's age and duration of infertility are considered important factors in making decisions regarding how to investigate, treat, and establish a reproductive prognosis. A significant association between $\mathrm{Yq}$ chromosome microdeletions and chromosomal disorders were strongly implicated in spermatogenesis. The frequency of Yq chromosome microdeletions and its type were associated with ethnic and regional differences [17]. Many studies had reported varying frequencies ranging from 1.3 to $55 \%[11,18,19]$. Many factors could explain this large variation such as ethnic and regional differences, sample 
Table 4. Correlation between chromosomal abnormalities, histological findings and Yq microdeletions.

\begin{tabular}{|llllll|}
\hline Patient $\mathbf{n}^{\circ}$ & Age, $\mathbf{Y}$ & Semen analysis & Karyotype & AZF region & Histological findings \\
\hline P3 & 47 & AZ & Normal & AZFc & SCOS \\
\hline P6 & 38 & SO & Normal & AZFc & - \\
\hline P13 & 45 & AZ & Normal & AZFc & SCOS \\
\hline P22 & 31 & AZ & $46, X$, del $Y / 45, X$ & AZFbc & MA \\
\hline P45 & 29 & SO & Normal & AZFc & - \\
\hline P62 & 41 & AZ & Normal & AZFc & SCOS \\
\hline P71 & 46 & AZ & Normal & AZFc & SCOS \\
\hline P81 & 44 & AZ & Normal & AZFb & MA \\
\hline
\end{tabular}

AZ: azoospermia, SO: severe oligozoospermia, SCOS: Sertoly cell only syndrome, MA: maturation arrest.

selection criteria and the STS selection to the research of Yq chromosome microdeletions. In this work, we found that $9.5 \%$ of patients with azoospermia or severe oligozoospermia had Yq microdeletions, which ranges with the reported frequency. However, our finding was higher than the previously reported value in our country; Rejeb et al. [20], in 2008 has reported 6.85\% and Hammami et al. [21] in 2014, reported $1.9 \%$. The small and unbalanced sample, patient selection criteria, methodological aspects and other factors explain the difference between the present and the previous study.

The most frequent chromosomal alteration was the Klinefelter syndrome 47,XXY, which was present in 5 patients (9.2\% of the azoospermic patients). Autosomal chromosome abnormalities weren't seen in our cohort. These results support others reports where sex chromosome anomalies and 47,XXY karyotype were the most frequent alterations in azoospermic males [22, 23]. Only one oligozoospermic patient (3.3\%) had abnormal karyotype $[47, \mathrm{XXY} / 46, \mathrm{XY}]$. The association between Yq microdeletions and primary spermatogenic failure (PSF) has been reported since the 1990s. Even though there are considerable variations in the frequencies reported, it appears that the mean is $7.6 \%$ in patients with PSF [17]. In our population, microdeletions were found in $9.5 \%$ of infertile males. The frequency of microdeletions in the azoospermic group is $11.1 \%$, which is higher than the $6.7 \%$ in the severe oligozoospermic group. However, these findings help us to realize that the frequency of Yq microdeletions in Tunisian infertile males is similar to that in other populations studied [2, 16, 24-26]. In this study, AZFa was not deleted, and the AZFc region has been the most frequently deleted (75\%) followed by the AZFb region (12.5\%) and AZFbc region $(12.5 \%)$. Data are in agreement with the literature, in which AZFc was often described as the most frequent deletion of the Y chromosome overlapping the DAZ gene family; encoding for proteins in testicular tissue containing RNA-binding motif which regulates RNA metabolism $[1,16]$. In this study AZFc was detected in patients with a heterogeneous phenotype because 4 patients were azoospermic and 2 were severely oligozoospermic. AZFb deletions were found in one azoospermic patient and AZFbc deletion in one other patient. It has been established that AZFa deletion leads to the absence of germ cells, AZFb deletion is responsible for maturation arrest and AZFc deletion leads to variable attempts of spermatogenesis. The type of Yq chromosome microdeletion (AZFa, b, c) has been proposed as a potential prognostic factor for sperm retrieval in men undergoing multiple TESE. Same of this finding were supported by our histological evaluation: all azoospermic and AZFc microdeleted patients showed a Sertoli cell only syndrome. However, AZFb and AZFbc showed a maturation arrest.

\section{Conclusion}

Our study shows that genetic abnormalities in infertile Tunisian patients are prevalent and similar to those reported in other countries. However, the authors recognize that the studied population described here is not representative of the total Tunisian population of infertile men. More studies, including men belonging to other ethnic groups or regions are needed to determine whether the frequencies of genetic abnormalities are much more variable in different infertile populations. Moreover, being aware of the existence of genetic abnormalities and microdeletions is useful to provide a correct diagnosis of male infertility, it allows the physician to refer the patient to adequate assisted reproduction technique and examine the value of testicular biopsy pertinence.

Before using IVF/ICSI genetic counseling should be provided, it must be considered that the son of a man with microdeletion may inherit this abnormality.

Conflict of interest: none of the authors has any conflict of interest to disclose. 
Acknowledgments. The authors would like to express their gratitude to all the staff of the IVF unit of Aziza Othmana Hospital and the laboratory of genetics, immunology and human pathology of the Faculty of sciences of Tunis.

\section{References}

1. Hopps CV, Mielnik A, Goldstein M, Palermo GD, Rosenwaks $\mathrm{Z}$, Schlegel PN. Detection of sperm in men with $\mathrm{Y}$ chromosome microdeletions of the AZFa, AZFb and AZFc regions. Hum Reprod $2013 ; 18: 1660-5$.

2. Foresta C, Moro E, Ferlin A. Y chromosome microdeletions and alterations of spermatogenesis. Endocrine Rev $2001 ; 22: 226-39$.

3. Perheentupa A, Vierula M, Jorgensen N, Skakkebæk NE, ChantotBastaraud S, McElreavey $\mathrm{K}$, et al. No association between the major Y chromosome haplogroup and semen quality in Finnish men. Poster viewing session-reproductive (EPI) genetics. Hum Reprod $2011 ; 26(1)$ : i278-96.

4. Elfeteh F, Wang R, Zhang Zhihong R, Jiang Y, Chen S, Liu R. Influence of genetic abnormalities on semen quality and male fertility: a four-year prospective study. Iran J Reprod Med 2014; 12 : 95-102.

5. O'Flynn O'Brein KL, Vaghese AC, Agarwal A. The genetic causes of male infertility: a review. Fertil Steril $2010 ; 93: 1-12$.

6. Tiepolo L, Zuffardi O. Localization of factors controlling spermatogenesis in the nonfluorescent portion of the human Y chromosome long arm. Hum Genet 1976; 34 : 119-24.

7. Egozcoue J, Blanco J, Anton E, Egozcue S, Sarrate Z, Vidal F. Genetic analysis of sperm and implication of severe male infertility- a review. Placenta $2003 ; 24: 62-5$.

8. Ceylan C, Ceylon GG, Serel TA. The azoospermia factor locus $\mathrm{c}$ region was found to be related to Klinefelter syndrome in Turkish patients. Genet Mol Res $2010 ; 9$ : 1229-33.

9. Vicdan A, Viedan K, Günalp S, Kence A, Akarsu C, Işik AZ, et al. Genetic aspects of human male infertility: the frequency of chromosomal abnormalities and $\mathrm{Y}$ chromosome microdeletion in severe male factor infertility. Eur J Obstet Gynecol Reprod Biol 2004 ; 117 : 49-54.

10. Kuroda-Kawaguchi T, Skaletsky H, Brown LG, Minx PJ, Cordum HS, Waterston RH, et al. The AZFc region of the Y chromosome features massive palindromes and uniform recurrent deletions in infertile men. Nat Genet $2001 ; 29: 279-86$.

11. Krausz C, Rajpert-De Meyts E, Frydelund-Larsen L, QuintanaMurci L, McElreavey K, Skakkebaek NE. Double-blind Y chromosome microdeletion analysis in men with known sperm parameters and reproductive hormone profiles: microdeletions are specific for spermatogenic failure. J Clin Endocrinol Metab 2001 ; 86 : 2638-42.

12. Kihaile PE, Yasui A, Shuto Y. Prospective assessment of Ychromosome microdeletions and reproductive outcomes among infertile couples of Japaneses and African origin. J Exp Clin Assist Reprod $2005 ; 2: 9$.

13. WHO. WHO Laboratory manual for the examination and processing of human semen. $5^{\mathrm{e}}$ Ed. Geneva, Switzerland : World Health Organization, 2010.

14. Moorehed PS, Nowell PC. Chromosome preparations of leukocytes cultured from human peripheral blood. Exp Cell Res 1960;20: 613-6.

15. Hook EB. Exclusion of chromosomal mosaicism: tables of $90 \%, 95 \%$ and 99\% confidence limits and comments on use. Am J Hum Genet $1997 ; 29: 94-7$.

16. Simoni M, Bakker E, Krausz C. EAA/EMQN best practice guidelines for molecular diagnosis of $y$-chromosomal microdeletions. State of the art. Int J Androl 2004 ; 27 : 240-9.

17. Krausz C, Forti G, McElreavey K. The $\mathrm{Y}$ chromosome and male fertility and infertility. Int J Androl 2003;26:70-5.

18. Osterlund C, Sergersteen E, Aver S, Pousette A. Low number of $Y$ chromosome deletions in infertile azoospermic men at a Swedich andrology centre. Int J Androl $2000 ; 23$ : 225-9.

19. Chiang HS, Yeh SD, Wu CC, Huang BC, Tsai HJ, Fang CL. Clinical and pathological correlation of the microdeletion of $\mathrm{Y}$ chromosome for the 30 patients with azoospermia and severe oligoasthenospermia. Asian $J$ Andro $2011 ; 6: 369-75$.

20. Rejeb I, M'rad R, Maazoul F, Trabelsi M, Ben Jemaa L, Chaabouni $\mathrm{M}$, et al. Y chromosome microdeletions in Tunisian infertile males. Pathol Biol $2008 ; 56: 111-5$.

21. Hammami W, Kilani O, Ben Khlifa M, Ayed W, Abdelhak S, Bouzouita A, et al. Prevalence of Y chromosome microdeletions in infertile Tunisian men. Ann Biol Clin 2014; 72 : 331-6.

22. Gardner RJM, Sutherland GR. Chromosome abnormalities and genetic counseling. $3^{e}$ ed. New York: Oxford University Press, 2004.

23. Collodel G, Moretti E, Capitani S, Piomboni P, Anichini C, Estenoz M, et al. TEM, FISH and molecular studies in infertile men with pericentric inversion of chromosome 9. Andrologia 2006; 38: 122-7.

24. Najmabadi H, Huang V, Yen P, Subbarao MN, Bhasin D, Banaag L, et al. Substantial prevalence of microdeletions of the Y-chromosome in infertile men with idiopathic azoospermia and oligozoospermia detected using a sequence-tagged site-based mapping strategy. J Clin Endocrinol Metab 1996; $81: 1347-52$.

25. Silber SJ, Alagappan R, Brown LG, Page DC. Y chromosome deletions in azoospermic and severely oligozoospermic men undergoing intracytoplasmic sperm injection after testicular sperm extraction. Hum Reprod $1998 ; 13: 3332-7$.

26. Kim SW, Kim KD, Paick JS. Microdeletions within the azoospermia factor subregions of the $\mathrm{Y}$ chromosome in patients with idiopathic azoospermia. Fertil Steril 1999; $72: 349-53$. 